\title{
Investigating Managers' Exploration and Exploitation Activities: The Influence of Top-down, Bottom-up, and Horizontal Knowledge Inflows
}

Tom J.M. Mom, Frans A.J. Van Den Bosch and Henk W. Volberda

\begin{tabular}{|l|l|}
\hline \multicolumn{2}{|l|}{ ERIM REPORT SERIES RESEARCH IN MANAGEMENT } \\
\hline ERIM Report Series reference number & ERS-2006-078-STR \\
\hline Publication & September 2006 \\
\hline Number of pages & 40 \\
\hline Persistent paper URL & \\
\hline Email address corresponding author & tmom@rsm.nl \\
\hline Address & Erasmus Research Institute of Management (ERIM) \\
& RSM Erasmus University / Erasmus School of Economics \\
& Erasmus Universiteit Rotterdam \\
& P.O.Box 1738 \\
& 3000 DR Rotterdam, The Netherlands \\
& Phone: + 31104081182 \\
& Fax: $\quad+31104089640$ \\
& Email: info@erim.eur.nl \\
& Internet: $\quad$ www.erim.eur.nl \\
\hline
\end{tabular}

Bibliographic data and classifications of all the ERIM reports are also available on the ERIM website: www.erim.eur.nl 


\section{ERASMUS RESEARCH INSTITUTE OF MANAGEMENT}

\section{REPORT SERIES \\ RESEARCH IN MANAGEMENT}

\begin{tabular}{|l|l|}
\hline ABSTRACT AND KEYWORDS \\
\hline Abstract & $\begin{array}{l}\text { This paper develops and tests hypotheses on the influence of a manager's knowledge inflows on } \\
\text { this manager's exploration and exploitation activities. Based on a survey among managers of a } \\
\text { leading electronics firm, the findings indicate, as expected, that top-down knowledge inflows of a } \\
\text { manager positively relate to the extent to which this manager conducts exploitation activities, } \\
\text { while they do not relate to a manager's exploration activities. Furthermore, as expected, bottom- } \\
\text { up and horizontal knowledge inflows of a manager positively relate to this manager's exploration } \\
\text { activities, while they do not relate to a manager's exploitation activities. We contribute to current }\end{array}$ \\
literature on exploration and exploitation by focusing on the manager level of analysis, and by \\
adding the importance of knowledge flow configurations to the literature on the impact of \\
organizational factors upon exploration and exploitation.
\end{tabular}




\title{
Investigating Managers' Exploration and Exploitation Activities:
}

The Influence of Top-down, Bottom-up, and Horizontal Knowledge Inflows

\author{
Tom J.M. Mom*
}

RSM Erasmus University

Department of Strategic Management and Business Environment

Erasmus University Rotterdam

P.O. Box 1738, 3000 DR Rotterdam, The Netherlands

Tel: +31 (0)10 408 2005; Fax: +31 (0)10 408 9013; E-mail: tmom@rsm.nl

\section{Frans A.J. Van Den Bosch}

RSM Erasmus University

Department of Strategic Management and Business Environment

Erasmus University Rotterdam

P.O. Box 1738, 3000 DR Rotterdam, The Netherlands

Tel: +31 (0)10 408 2005; Fax: +31 (0)10 408 9013; E-mail: fbosch@rsm.nl

\section{Henk W. Volberda}

RSM Erasmus University

Department of Strategic Management and Business Environment

Erasmus University Rotterdam

P.O. Box 1738, 3000 DR Rotterdam, The Netherlands

Tel: +31 (0)10 408 2005; Fax: +31 (0)10 408 9013; E-mail: hvolberda@rsm.nl

September 20, 2006

Accepted for publication in Journal of Management Studies

*Corresponding author. We would like to thank, Charles Baden-Fuller, Erwin Danneels, Gerry George, Justin Jansen, Raymond Van Wijk, and Ernst Verwaal for their useful comments, and Julien de Jong for assisting us in collecting the data. Previous versions of this paper have been presented at the ERIM workshop on Ambidextrous Strategies and Innovation, Rotterdam, The Netherlands, November 7, 2005 , and at the Copenhagen Conference on Strategic Management, Copenhagen, Denmark, December 14-15, 2005 . 


\title{
Investigating Managers’ Exploration and Exploitation Activities:
}

The Influence of Top-down, Bottom-up, and Horizontal Knowledge Inflows

\begin{abstract}
This paper develops and tests hypotheses on the influence of a manager's knowledge inflows on this manager's exploration and exploitation activities. Based on a survey among managers of a leading electronics firm, the findings indicate, as expected, that top-down knowledge inflows of a manager positively relate to the extent to which this manager conducts exploitation activities, while they do not relate to a manager's exploration activities. Furthermore, as expected, bottom-up and horizontal knowledge inflows of a manager positively relate to this manager's exploration activities, while they do not relate to a manager's exploitation activities. We contribute to current literature on exploration and exploitation by focusing on the manager level of analysis, and by adding the importance of knowledge flow configurations to the literature on the impact of organizational factors upon exploration and exploitation.
\end{abstract}

WORD COUNT ABSTRACT: 133

Key words: exploitation, exploration, top-down, bottom-up, horizontal, knowledge inflows, manager-level 


\section{Investigating Managers’ Exploration and Exploitation Activities: The Influence of Top-down, Bottom-up, and Horizontal Knowledge Inflows}

Firms in a dynamic environment are challenged to both explore new possibilities in order to cope with future changes in the business environment and exploit old certainties to meet today's business demands (March, 1991). Previous research suggests, however, that firms face difficulties to both explore and exploit; current literature and management practice could benefit from increased understanding about how firms may manage both exploration and exploitation (Cf. Benner and Tushman, 2003; Gibson and Birkinshaw, 2004; Levinthal and March, 1993; Tushman and O'Reilly, 1996).

This paper aims to contribute to this by investigating managers' exploration activities such as searching for, discovering, creating, and experimenting with new opportunities (Cf. March, 1991, p. 71), and managers' exploitation activities such as selecting, implementing, improving and refining existing certainties (Cf. March, 1991, p. 71). Exploration and exploitation are typically studied at the firm-level (e.g. Benner and Tushman, 2002; 2003; He and Wong, 2004) or at the business unit-level (e.g. Gibson and Birkinshaw, 2004; Jansen et al., 2006). However, there is a lack of conceptually and empirically validated understanding about exploration and exploitation at the manager level of analysis. This is quite surprising as previous research in organizational learning (Crossan et al., 1999; Vera and Crossan, 2004), strategy research (Burgelman, 1983b, 1991; Floyd and Lane, 2000; Rajagopalan and Spreitzer, 1996; Rosenbloom, 2000; Trispsas and Gavetti, 2000) and technological innovation (Duncan, 1976; Tushman and O'Reilly, 1996) indicates that firm or unit level exploration and exploitation to a large extent originate in the exploration and exploitation activities of their managers. These studies indicate that insight into managers' exploration and exploitation activities and 
into how these activities may be influenced, benefit our understanding about how to build exploration and exploitation within a business-unit or firm.

Taking a knowledge perspective (Grant, 1996; Gupta and Govindarajan, 2000; Kogut and Zander, 1992; Schulz, 2001), this paper investigates how the acquisition of knowledge from other persons and/or units in the same organization by a manager, influence this manager's exploration and exploitation activities. On the basis of studies of intra-organizational knowledge flows (Gupta and Govindarajan, 2000; Schulz, 2003), we will conceptualize and operationalize knowledge acquisition by a manager in terms of a manager's knowledge inflows. Previous research indicates that knowledge acquisition is an important explanatory factor for exploration as well as exploitation related activities within a firm. In the area of technological innovation, scholars have examined the impact of knowledge acquisition by firms, as reflected in citation patterns within patent applications, in terms of the extent to which innovations tend to be incremental or radical (e.g. Katila and Ahuja, 2002; Nerkar, 2003; Rosenkopf and Nerkar, 2001). Studies in the field of organizational learning indicate that the acquisition of knowledge is a primary mechanism by which not only firms but also organization members learn from each other (Fiol \& Lyles, 1985; Huber, 1991; Levitt and March, 1988). Such learning through the acquisition of knowledge may be either exploratory (e.g. Inkpen, 1996; Nonaka, 1994), and/or exploitative (Adler et al., 1999; Levin, 2000).

With respect to managers, previous conceptual investigations and case studies in the field of strategy research indicate that exploration and exploitation related activities of managers are facilitated by vertical knowledge flows, i.e. by managers' top-down and/ or bottom-up knowledge inflows (Burgelman, 1983b; 1991; Floyd and Lane, 2000; Rivkin and Siggelkow, 2003; Van Cauwenbergh and Cool, 1982). Others point to the important role of horizontal knowledge flows within an organization with regard to 
understanding exploration and exploitation related activities (e.g. Gupta and Govindarajan, 1991; Mom et al., 2005; Nonaka, 1994; Schulz, 2003; Subramanian and Youndt, 2005). Therefore, we will investigate not only top-down and bottom-up knowledge inflows but also horizontal knowledge inflows of managers. More specifically, we will focus on the following research question: how do top-down, bottom-up, and horizontal knowledge inflows of managers affect their exploration activities and exploitation activities?

This paper has three contributions. First, it delivers a contribution to the current literature on exploration and exploitation (e.g. Benner and Tushman, 2002; Gibson and Birkinshaw, 2004; He and Wong, 2004; March, 1991; Tushman and O’Reilly, 1996) which lacks conceptually and empirically validated understanding about exploration and exploitation at the level of the manager by examining managers' exploration and exploitation activities. We also developed scales which assess managers' levels of exploration and exploitation as such scales were not available yet. Second, the paper adds the importance of knowledge flow configurations to the literature on the impact of organizational factors upon exploration and exploitation (e.g. Adler et al., 1999; Benner and Tushman, 2002; 2003; Ghemawat and Ricart I Costa, 1993; Gibson and Birkinshaw, 2004; Jansen et al., 2006; Leana and Barry, 2000; McGrath, 2001; Rivkin and Siggelkow, 2003; Sheremata, 2000; Van Den Bosch et al., 1999) by developing and testing a framework which contributes to the understanding of how knowledge inflows of managers influence their exploration and exploitation activities. Third, the paper also contributes to strategy process research (e.g. Bartlett and Ghoshal, 1993; Floyd and Lane, 2000; Van Cauwenberg and Cool, 1982). Whereas the vertical exchange of knowledge between managers plays an important role in studies of strategy process research, to our 
knowledge, quantitative empirical studies seem to be lacking. Moreover, this paper illustrates the role of horizontal knowledge flows as well.

The paper is structured as follows. The next section presents the theoretical background of the paper. It delves into the concepts of exploration, exploitation, and knowledge inflows at the manager level, and it examines how intra-organizational knowledge inflows of a manager affect this manager's level of exploration and exploitation. After advancing the hypotheses, the method section provides details about the sample, data collection, and the development and validation of the measurement instruments. Next, we present the empirical findings and conclude with a discussion of the results, implications, and issues for further research.

\section{THEORY AND HYPOTHESES}

\section{Exploration and Exploitation at the Manager Level}

This study departs from March (1991) by conceptualizing exploration and exploitation at the manager level. March (1991, p. 71) considers the relation between exploration, which includes 'things captured by terms such as search, variation, risk taking, experimentation, play, flexibility, discovery, innovation', and exploitation, which includes 'such things as refinement, choice, production, efficiency, selection, implementation, execution' in organizational learning. Studies of organizational learning indicate that the essence of exploration activities is creating variety in experience (Bontis et al., 2002; Holmqvist, 2004; Levinthal and March, 1993; McGrath, 2001) which is associated with broadening a manager's existing knowledge base (Cf. Katila and Ahuja, 
2002; Levinthal and March, 1993; Sidhu et al., 2004). Such exploration activities of managers include searching for new organizational norms, routines, structures, and systems (Crossan et al., 1999; Nooteboom, 2000; Zollo and Winter, 2002), experimenting with new approaches towards technologies, business processes, or markets (McGrath, 2001), innovating and adopting a long-term orientation (Duncan, 1976; Tushman and O'Reilly, 1996), and reconsidering existing beliefs and decisions (Floyd and Lane, 2000; Ghemawat and Ricart I Costa, 1993; Rivkin and Siggelkow, 2003). The essence of exploitation activities is creating reliability in experience (Bontis et al., 2002; Holmqvist, 2004; Levinthal and March, 1993) which is associated with deepening a manager's existing knowledge base (Cf. Katila and Ahuja, 2002; Levinthal and March, 1993). Such exploitation activities of managers include using and refining their existing knowledge (Levinthal and March, 1993), applying, improving, and extending existing competences, technologies, processes and products (March, 1991), focusing on production and adopting a rather short-term orientation (Duncan, 1976; Tushman and O’Reilly, 1996), and elaborating on existing beliefs and decisions (Floyd and Lane, 2000; Ghemawat and Ricart I Costa, 1993; Rivkin and Siggelkow, 2003).

\section{Knowledge Inflows}

Concepts such as knowledge sharing, knowledge exchange, and knowledge flows are sometimes used interchangeably in studies (Cf. Schulz, 2001). However, whereas knowledge sharing and knowledge exchange imply a reciprocal relationship in terms of transfers of knowledge, the concept of knowledge flows allows greater precision about the directionality of the knowledge being transferred. That is, knowledge outflows are associated with a donor providing a recipient with knowledge, where the knowledge 
donor is the focal unit of analysis (Gupta and Govindarajan, 2000; Schulz, 2001). Schulz (2001), for instance, investigated among others the impact of exploration and exploitation learning processes within a unit on this unit's knowledge outflows. Knowledge inflows are associated with a recipient acquiring knowledge from a donor, where the knowledge recipient is the focal unit of analysis (Gupta and Govindarajan, 2000; Schulz, 2003). As we try to understand how knowledge, that a manager acquires from other persons and/ or units in the organization, impacts upon this manager's exploration and exploitation activities, the focus of this paper will be on a manager's knowledge inflows. For these knowledge inflows, both the knowledge donor and/ or recipient may be the initiator.

Notions of knowledge flows vary somewhat in the literature (Cf. Schulz, 2001: 662). Whereas some authors focus on certain types of knowledge such as the transfer of skills and technology (Tsai, 2002), the transfer of business practices (Szulanski, 1996), or the transfer of tacit knowledge (Kogut and Zander, 1993; Subramaniam and Venkatraman, 2001), we follow Gupta and Govindarajan (2000) and Schulz (2001; 2003) by adopting a broader notion on knowledge flows. That is, based on Schulz' (2001) and Gupta and Govindarajan's (2000) definitions of knowledge flows, we define the knowledge inflows of a manager as the 'aggregate volume' (Schulz, 2001: 662) of tacit and explicit knowledge pertaining to several domains such as technology, products, processes, strategies, and markets, which a manager receives or gathers per unit of time, from other persons and units within the organization. We do not intend to capture inflows of operational or financial data or the taking of orders. A manager may use different channels to receive or gather knowledge as conceptualized in this study, for instance, by telephone, e-mail, regular mail, through formal meetings, informal face-to-face contacts, and by using shared technologies such as the company's intranet. Based on studies of intra-organizational knowledge flows (e.g. Gupta and Govindarajan, 2000; Schulz, 
2003), we distinguish top-down, bottom-up, and horizontal knowledge inflows of managers.

\section{The Impact of Knowledge Inflows on a Manager's Exploration and Exploitation}

\section{Activities}

Top-down knowledge inflows of a manager proceed down the hierarchy and are associated with knowledge coming from persons and units at higher hierarchical levels than the manager. Within large multi-unit firms, top-down flows of knowledge are typically confined to the vertical chains of organizational units specialized in functional, technological, geographic, or product-market related areas of expertise (Gupta and Govindarajan, 1991; Hedlund, 1994). This implies that the scope of top-down inflows of knowledge is likely to be narrow (Winter and Szulanski, 2001), i.e. closely related and even restricted to the recipient's specialized areas of expertise. Consequently, top-down inflows of knowledge increase the depth of the recipient manager's existing knowledge base rather than the breadth; they enable the recipient to increase, refine, or improve his or her expertise in a limited or specialized area (Cf. Katila and Ahuja, 2002).

Moreover, top-down inflows of knowledge tend to be rather unambiguous; i.e. they possess a clear and proven understanding of cause-effect relationships (Egelhoff, 1991), and their relevance with respect to improving the recipient's current activities is normally well-known (Schulz, 2003). Consequently, top-down knowledge inflows allow the recipient manager to respond to problems in familiar ways, and to increase the manager's ability to effectively and efficiently perform existing activities (Daft and Lengel, 1986; Galunic and Rodan, 1998); i.e. they allow the recipient manager to increase reliability, rather than variety, in experience. 
The arguments above indicate that top-down knowledge inflows of a manager, being rather narrow and unambiguous (Egelhoff, 1991; Schulz, 2003; Winter and Szulanski, 2001), positively relate to the manager's exploitation activities, but are unlikely to relate to the manager's exploration activities. However, senior management can influence middle and front-line managers' exploration activities by means other than by top-down knowledge inflows. Senior management, for example, may trigger exploration within a firm by changing the characteristics of the organizational structure such as increasing other managers' participation in decision making or decreasing managers' formalization of tasks (e.g. Duncan, 1976; McGrath, 2001; Tushman and O’Reilly, 1996), or by implementing cross-functional interfaces (Egelhoff, 1991; Galbraith, 1973). Other studies argue that the CEO can trigger managers' exploration activities, for instance, by fostering a culture which allows for deviant behavior and differing opinions and ideas (Volberda, 1998), or by challenging the strategic status quo of the firm (Bartlett and Ghoshal, 1993; O'Reilly and Tushman 2004).

Although the literature indicates that higher level managers may exert an influence on other managers' exploration activities by other means than top-down knowledge inflows, we argue that knowledge which comes from higher hierarchical levels does not relate to the recipient manager's exploration activities, but rather will be positively related to this manager's exploitation activities, suggesting the following hypothesis:

Hypothesis 1: Top-down knowledge inflows of a manager will be positively related to the extent to which this manager engages in exploitation activities. 
Bottom-up knowledge inflows of a manager are associated with knowledge

coming from persons and units at lower hierarchical levels than the manager. Contrary to bottom-up knowledge inflows of a manager, bottom-up inflows of data are rather unambiguous and provide the recipient manager with data in standardized and formalized ways about, for instance, the current performance of the organization; motivating the recipient manager to engage in exploitation activities (Brady and Davies, 2004; Sanchez and Heene, 1996). Bottom-up inflows of knowledge, however, do not follow these standardized and formalized paths in an organization, rather they come about in ad hoc, random, unpredictable, and reciprocal interactions between the knowledge donor and knowledge recipient (Burgelman, 1983b) and typically demand qualitative rather than quantitative changes of existing activities (Sanchez and Heene, 1996). Consequently, bottom-up knowledge inflows of a manager do not relate to this manager's reliability in experience or to the depth of this manager's existing knowledge base; they are unlikely to impact upon the extent to which this manager engages in exploitation activities.

Regarding exploration, bottom-up knowledge inflows of a manager are likely to increase variety in experience; previous conceptual and case studies in the field of strategy research illustrate that front-line managers are directly confronted with new technological developments, unexpected problems, and changing market conditions and customer demands (Branzei et al., 2004; Burgelman, 1983b; Sheremata, 2000; Van de Ven, 1980) and that bottom-up inflows of knowledge provide higher level managers with an increased understanding of changes regarding existing technologies, products, processes, and markets and with increased understanding of new or emerging technologies, markets, customer needs, or internal initiatives (Brady and Davies, 2004; Branzei et al., 2004; Burgelman, 1983b; Floyd and Lane, 2000). Consequently, a manager's bottom-up knowledge inflows may be a major source of exploratory learning 
by adding new knowledge to the recipient's existing knowledge base (Brady and Davies, 2004); bottom-up knowledge inflows may trigger knowledge recipient managers to revise current beliefs, to search for, develop, and experiment with various novel solutions to emerging problems, and to redefine strategic decisions (Bartlett and Ghoshal, 1993; Burgelman, 1983b; Floyd and Lane, 2000; Kimberly, 1979; Quinn, 1985).

The arguments above suggest that bottom-up knowledge inflows of a manager do not relate to this manager's exploitation activities, but rather positively influence this manager's exploration activities, suggesting the following hypothesis:

Hypothesis 2: Bottom-up knowledge inflows of a manager will be positively related to the extent to which this manager engages in exploration activities.

Horizontal knowledge inflows of a manager are associated with knowledge coming from peer managers in the same organizational unit, or coming from other units at the same hierarchical level. Acquiring horizontal knowledge is enabled by crossfunctional interfaces characterized by rich and dense personal reciprocal interactions (Galbraith, 1973; Subramaniam and Youndt, 2005; Tsai, 2001). Through such reciprocal personal interactions, managers typically acquire knowledge from other parts of the organization which is rather ambiguous, complex and tacit (Egelhoff, 1991; Daft and Lengel, 1986). Acquiring this knowledge is less effective for dealing with or improving analyzable and rather unequivocal tasks and associated problems (Egelhoff, 1991; Daft and Lengel, 1986). Hence, horizontal knowledge inflows are unlikely to influence reliability in managers' experience; they do not relate to a manager's exploitation activities. 
However, the personal and reciprocal interactions by which a manager acquires horizontal knowledge, contribute to this manager's ability to interpret ambiguous and complex issues and to build understanding about new acquired knowledge (Daft and Lengel, 1986; Jansen et al., 2005), enabling the manager to increase variety in experience (Katila and Ahuja, 2002; Van Den Bosch and Van Wijk, 1999). Consequently, by stimulating cross-fertilization or (re-)combinations of different kinds of knowledge, horizontal inflows of knowledge have been found to enhance innovation and the creation of new knowledge at the recipient level (e.g. Grant, 1996; Kogut and Zander, 1992; Lawrence and Lorsch, 1967).

Moreover, horizontal knowledge inflows cross functional, disciplinary, and technological areas (Grant, 1996; Hedlund, 1994; Leonard-Barton, 1995; Thompson, 1967). Consequently, their scope is likely to be broad (Winter and Szulanski, 2001); they are distant or unrelated to the recipient's existing knowledge base, increasing the breadth, rather than the depth, of the manager's existing knowledge base.

As the arguments above indicate that horizontal knowledge inflows of a manager are unlikely to relate to this manager's reliability in experience or to the depth of this manager's knowledge base, we argue that horizontal knowledge inflows are not related to a manager's exploitation activities. However, as horizontal knowledge inflows increase the breadth of the manager's knowledge base and variety in experience, we argue that these knowledge inflows positively relate to the manager's exploration activities.

Hypothesis 3: Horizontal knowledge inflows of a manager will be positively related to the extent to which this manager engages in exploration activities. 


\section{METHOD}

\section{Data Collection}

The empirical research was conducted at an international electronics firm, which ranks among the top 10 in the electronics industry on the Fortune Global 500 (2005) in terms of revenue. Research in this firm was carried out in one of the three divisions of the firm's semiconductor group. Regarding the selection of this firm and its semiconductor group; several challenges in the semiconductor industry, such as rapid technological progress, manufacturing complexity, ongoing trends of globalization and miniaturization, and fierce competition on first-to-market, low costs, and innovation, compel firms active in the semiconductor industry to both explore and exploit (Burgelman, 2002; Henisz and Macher, 2004; Iansiti, 2000; Rosenkopf and Nerkar, 2001). Investigating managers' exploration and exploitation activities, as this study does, calls for examining managers whose firms are confronted with pressures to explore and pressures to exploit, as this increases the probability of observing managers' exploration activities and managers' exploitation activities. Previous empirical studies that investigate issues related to exploration and exploitation, especially those in the field of technological innovation, also take firms active in the semiconductor industry as an empirical setting (e.g. Brown \& Eisenhardt, 1997; Danneels, 2002; Rosenkopf and Nerkar, 2001). Furthermore, we chose the selected division because it serves multiple markets with different degrees of dynamism and competitiveness, which increases the probability of observing various levels of managers' exploration and exploitation activities (Cf. Cheng and Van De Ven, 1996; Garcia et al., 2003; Luo, 2002). The other group's two divisions each serve a single market. Finally, regarding the selection logic, the knowledge literature indicates the value 
of examining firms whose members poses high levels of specialized knowledge when investigating intra-organizational knowledge flows, as the transfer of knowledge between individuals plays an important role in such firms, and hence increases the probability of observing various levels and different directionalities of knowledge flows (Kogut and Zander, 1992; Grant, 1996). Technology firms, like semiconductor firms, are cited examples of firms whose members possess high levels of specialized knowledge (Cf. Iansiti, 2000; Smith et al., 2005).

The selected division employs over 7,000 employees and has R\&D and production facilities in the Americas, Asia, and Europe. It consists of a headquarters, a production support unit, and five product-market related organizational units. One of these product-market units concentrates on the innovative part of the automotive industry (product market unit 1), one unit relates to niche products (product market unit 2), and three units relate to general application, standard, and interface products (respectively product market units 3, 4, and 5) for various industries. All organizational units face challenges to both explore and exploit, but we expect managers of the production support unit, however, to engage more in exploitation activities as compared to the managers of the product-market related units, as the production support unit's focus is primarily centered on operational efficiency. Based on external data, we also expect managers of the product-market unit which is active in the innovative part of the automotive industry and managers of the product-market unit which concentrates on niche-products to focus more on exploration activities as compared to the managers of the other organizational units, as their business environments are the most dynamic ones.

In cooperation with the division's headquarters, questionnaires were made available electronically to all 225 managers of the five product-market units and the production support unit. These managers are responsible, for instance, for a functional 
area, a geographical area, or a particular product or technology. To ensure

confidentiality, we agreed not to reveal the name of the manager; 136 managers returned the questionnaire, yielding a response rate of 60 percent. List-wise deletion of cases with missing values reduced the final sample to 104 . We examined differences between respondents and non-respondents to test for non-response bias. Chi-square tests indicate that the hypothesis that the distribution of the respondents over the organizational units and functional areas corresponds to the population's distribution, cannot be rejected ( $p<$ $.05 ; \alpha=.05)$. We also compared early and late respondents in terms of demographic characteristics and model variables. No significant differences $(t$-test; $p<.05)$ appeared, indicating that non-response bias is not a problem.

\section{Measures}

Exploration and Exploitation. As appropriate scales at the individual level of analysis were not yet available in the literature we constructed scales for exploration and exploitation. We developed seven exploration activity items and seven exploitation activity items based on the features by which March (1991, p. 71) characterizes the constructs of exploration and exploitation. The exploration scale determines the extent to which a manager engaged in exploration activities last year while the exploitation scale determines the extent to which the manager engaged in exploitation activities last year. To enhance the construct validity of the scales and their items, we conducted in-depth interviews with 12 managers with various functions at different organizational units. Based on these interviews, five items were reworded. Factor analyses with all 14 items, based on the survey data, revealed that two summated scales could be constructed; one exploration scale with five exploration items and one exploitation scale with six 
exploitation items. These items are reported in Table I. Managers responded to the question 'To what extent did you, last year, engage in work related activities that can be characterized as follows:', after which they judged the exploration and exploitation items. The reliability of the summated scales as represented by Cronbach's alpha is .86 for the exploration scale and .81 for the exploitation scale.

\section{INSERT TABLE I ABOUT HERE}

Knowledge inflows. Top-down knowledge inflows are associated with knowledge coming from persons and units at higher hierarchical levels than the recipient manager. Bottom-up knowledge inflows are associated with knowledge coming from persons and units at lower hierarchical levels than the recipient manager. Horizontal knowledge inflows are associated with knowledge coming from persons and units at the same hierarchical level. Following Gupta and Govindarajan (2000) and Schulz (2001) and our associated conceptualization of knowledge, we informed respondents that we are not interested in operational or financial data or the taking of orders, but rather in tacit and explicit knowledge pertaining to: technologies, processes, systems, products, strategies, and markets. Managers were furthermore instructed to think about different channels through which knowledge might flow such as telephone, e-mail, regular mail, formal meetings, informal face-to-face contacts, and shared technologies such as the company's intranet. Subsequently, following Gupta and Govindarajan (2000: 483) and Schulz (2001: 680), the question to which managers responded was phrased as follows: 'To what extent did you, last year, receive or gather knowledge from:', after which they 
judged eight knowledge inflow items. These items are reported in Table I. The reliability as represented by Cronbach's alphas of the scales are .79 for the top-down knowledge inflows scale (three items), .80 for the bottom-up knowledge inflow scale (two items), and .74 for the horizontal knowledge inflow scale (three items).

Control Variables. The empirical research within the selected division took place in the five product-market units and the production support unit. Using five dummy variables, for each product-market unit one, we intended to control for organizational unit and environmental effects. Regarding organizational unit effects, Gibson and Birkinshaw (2004) showed that contextual factors of an organizational unit impact upon the levels of exploration and exploitation within these units. Several authors argue that environmental effects, like environmental dynamism, impact upon exploration and exploitation (Levinthal and March, 1993; Lewin et al., 1999). Sidhu et al. (2004), for instance, showed that the greater environmental dynamism, the greater an organization's exploration orientation. Although managers of all units face challenges to both explore and exploit, as indicated above, we expect managers of the production support unit to focus more on exploitation activities as compared to managers of the other productmarket units. We also expect managers of the automotive and niche-products productmarket units to focus more on exploration activities as compared to the managers of the other units.

Functional areas within the division relate in particular to research $\&$ development and marketing \& sales. Other functional areas are finance, human resources and logistics. Using two dummy variables, one for research \& development and another for marketing \& sales, we intended to control for functional effects. We expect managers in research \& development to engage more in exploration activities as compared to managers in marketing \& sales and the other functional areas. Exploration related 
activities like searching, experimenting, and discovering constitute an important part of R\&D.

Measure and Model Structure Tests. We conducted exploratory and confirmatory factor analyses including all items pertaining to the independent and dependent variables; the exploration items, exploitation items, top-down, bottom-up, and horizontal knowledge inflow items. Results of the exploratory factor analysis (see Table I) indicate that the five variables were appropriately constructed; eigenvalues for each factor were greater than 1 , all items loaded on their appropriate factors at greater than .62 , and no item cross-loading was greater than .33 . We used EQS to conduct a confirmatory factor analysis to test for discriminant validity of the constructs. We allowed each item to load only on the factor for which it was a proposed indicator. Results indicate that the five factor model fits the data well $(\mathrm{NFI}=.93, \mathrm{CFI}=.94$, RMSEA < .06). Moreover, a comparison of a one-factor model with a two-factor model for every pair among the five factors shows a significant improvement in fit for each of the ten pairs $\left(\Delta \chi_{1 \mathrm{df}}^{2}\right.$ between 43.56 and $\left.221.69 ; p<.001\right)$, providing evidence of discriminant validity (Bagozzi and Philips, 1982).

ANALYSIS AND RESULTS

INSERT TABLE II ABOUT HERE 
Table II presents descriptive statistics and correlations for the variables as used in the study. T-tests show that the means of managers' exploitation (5.27) and exploration (5.28) activities do not significantly differ from each other. However, the means of managers' knowledge inflows do differ from each other; the mean of top-down knowledge inflows $(3.78)$ is significantly $(p<.001)$ lower than the means of bottom-up (5.56) and horizontal (4.60) knowledge inflows. This may indicate that, as intended, the top-down knowledge inflow scale did not measure the taking of commands or orders, as in that case, the extent of top-down 'knowledge' inflows would probably have been larger. Furthermore, the mean horizontal knowledge inflows is significantly $(\mathrm{p}<.001)$ lower than the mean of bottom-up knowledge inflows. Furthermore, Table II shows that several of the independent and control variables significantly relate to each other. To examine the issue of multicollinearity, we calculated variance inflation factors (VIF) in each of the regression equations. VIF factors are between 2.2 and 1.3 , which is well below the below the rule-of-thumb cut-off of 10 (Hair et al, 1998).

INSERT TABLE III ABOUT HERE

Table III presents the results of the hierarchical regression analyses for exploitation (models $1 \mathrm{a}$ and $1 \mathrm{~b}$ ) and exploration (models $2 \mathrm{a}$ and $2 \mathrm{~b}$ ). Models $1 \mathrm{a}$ and $2 \mathrm{a}$ are the baseline models containing the control variables. Models $1 \mathrm{~b}$ and $2 \mathrm{~b}$ represent the full models considering the effect of the knowledge inflows. To discuss the results we will focus on the full models. Regarding the control variables, model $1 \mathrm{~b}$ shows that managers of product-market unit $1(\beta=-.28, p<.05)$, i.e. the unit which concentrates on 
the innovative part of the automotive industry, and managers of product-market unit 2 ( $\beta$ $=-.29, p<.05)$; i.e. the unit which concentrates on niche products, tend to engage significantly less in exploitation activities than managers in the production support unit. This is not surprising as the production support unit's focus is strongly on operational efficiency, whereas the business environments of the two product market units concerned are the most dynamic ones. Model $2 \mathrm{~b}$ shows that managers in the functional areas $\mathrm{R} \& \mathrm{D}$ $(\beta=.27, p<.01)$ and marketing $\&$ sales $(\beta=.26, p<.01)$ engage more in exploration activities than managers in other functional areas. The findings regarding R\&D are in line with our expectations. Regarding marketing \& sales, the company launched a new company-wide publicity campaign about a year preceding the survey which may have forced these managers to engage more in exploration activities than we initially expected. Regarding managers' knowledge inflows and their exploitation activities, model $1 \mathrm{~b}$ shows that top-down knowledge inflows of a manager positively relate to the extent to which this manager engages in exploitation activities $(\beta=.24, p<.05)$, supporting hypothesis 1. Moreover, as expected, both bottom-up and horizontal knowledge inflows do not significantly relate to a manager's exploitation activities. Regarding managers' knowledge inflows and their exploration activities, model $2 \mathrm{~b}$ shows, consistently with hypotheses 2 and 3, that both bottom-up knowledge inflows $(\beta=.32, p<.01)$ and horizontal knowledge inflows $(\beta=.26, p<.05)$ of a manager positively relate to the extent to which this manager engages in exploration activities. Moreover, as expected, top-down knowledge inflows of a manager do not significantly relate to this manager's exploration activities. 
Firms face difficulties in managing exploration and exploitation concurrently, as the two tend to drive out each other (March, 1991; Levinthal and March, 1993). Previous research illustrates how organizational factors impact upon firm or unit level exploration and exploitation processes or outcomes (e.g. Adler et al., 1999; Benner and Tushman, 2002; 2003; Ghemawat and Ricart I Costa, 1993; Gibson and Birkinshaw, 2004; Jansen et al, 2006; Leana and Barry, 2000; Levinthal and March, 1993; Rivkin and Siggelkow, 2003; Sheremata, 2000). There is, however, a lack of conceptually and empirically validated understanding about exploration and exploitation activities at the manager level of analysis and how these activities are influenced by a manager's intra-organizational knowledge inflows. This paper aims to contribute to this understanding.

Regarding the relationship between exploration and exploitation, March (1991, p. 72) argues that a trade-off exists between exploration and exploitation at several levels. Recently, studies show that exploration and exploitation are not mutually exclusive at the firm-level (He and Wong, 2004) or business unit-level (Gibson and Birkinshaw, 2004). With respect to exploration and exploitation at the level of the manager level, this paper's findings support the proposition that exploration and exploitation are not mutually exclusive at the manager level as well. Whereas some managers engage more in exploration activities as compared to exploitation activities, or the other way around, other managers have high levels of both exploration and exploitation. This may be illustrated by the non-significant correlation between exploration and exploitation (Table II), and by the results of the exploratory (Table I) and confirmatory factor analyses, which empirically indicate that, although exploration and exploitation are two separate dimensions, managers may combine both exploration and exploitation activities. 
Regarding the influence of a manager's knowledge inflows on this manager's exploration and exploitation activities, this paper illustrates, as expected, that top-down knowledge inflows of a manager positively relate to the extent to which this manager conducts exploitation activities, while they do not relate to a manager's exploration activities. Furthermore, as expected, bottom-up and horizontal knowledge inflows of a manager positively relate to the extent to which this manager conducts exploration activities, while they do not relate to a manager's exploitation activities. Accordingly, this study indicates that increasing managers' top-down knowledge inflows within an organization, without enabling bottom-up or horizontal inflows, is likely to increase managers' exploitation activities without increasing their exploration activities. This would lead to exploitation driving out exploration. Furthermore, stimulating managers' bottom-up and/or horizontal knowledge inflows within an organization, without stimulating top-down knowledge flows, is likely to increase exploration activities of managers without increasing their exploitation activities. This would lead to exploration driving out exploitation. Moreover, a logical deduction of the hypotheses and empirical findings would indicate that the more a manager acquires both top-down and bottom-up knowledge flows, or both top-down and horizontal knowledge flows, the higher the levels of both exploration and exploitation activities this manager may engage in.

Furthermore, the findings of this paper illustrate how managers' knowledge inflows enable or inhibit them in terms of responding to particular ways in which a firm may combine exploration and exploitation. We distinguish on the basis of Volberda (1998) three main organizational responses for combining exploration and exploitation; spatial separation, temporal separation and synthesis. Each of these responses places different demands on managers' exploration activities and exploitation activities. In spatial separation, both exploration and exploitation take place, but in different places in 
the organization. For instance, according to proponents of structural ambidexterity (e.g. Benner and Tushman, 2003; Duncan, 1976; Tushman and O'Reilly, 1996), top- or corporate-level managers should engage in both exploration and exploitation activities, whereas business unit managers should focus on either exploration or exploitation activities, depending on the focus of their business unit which is either explorative or exploitative. Our findings illustrate that in a firm characterized by spatial separation, topdown knowledge inflows would be of particular value for managers in places focusing on exploitation, whereas bottom-up and/ or horizontal knowledge inflows would be of particular value for managers in places focusing on exploration.

Studies of technological innovation and strategic renewal indicate that firms may deal with tensions between exploration and exploitation by temporally separating the two (Audia et al., 2000; Shepard, 1967; Tushman and Anderson, 1986). This implies for managers that they shift their focus over time from pursuing incremental innovations or stability to pursuing radical innovations or strategic renewal, or vice versa. Our findings illustrate that in a firm characterized by temporal separation, top-down knowledge inflows would be of particular value for managers in time periods focusing on exploitation, whereas bottom-up and/ or horizontal knowledge inflows would be of particular value for managers in time periods focusing on exploration.

The third identified organizational response for pursuing both exploration and exploitation is by synthesizing them; that is by creating organizational units in which the tensions between exploration and exploitation are reconciled (Gibson and Birkinshaw, 2004). Such units combine various contradictory elements like centripetal and centrifugal forces (Sheremata, 2000), routine and non-routine tasks (Adler et al., 1999), and hard and soft processes or systems (Gibson and Birkinshaw, 2004). These elements should encourage managers to conduct both exploration and exploitation related activities, or as 
Gibson and Birkinshaw (2004, p. 210) point out these elements should enable them 'to make their own judgments about how to divide their time between conflicting demands for alignment and adaptability'. Our findings illustrate that in firms or units aiming at synthesizing exploration and exploitation, a combination of both top-down and bottomup, or a combination of both top-down and horizontal knowledge inflows would be of particular value for managers.

The paper may also deliver a contribution to strategy process research (e.g. Bartlett and Ghoshal, 1993; Floyd and Lane, 2000; Rivkin and Siggelkow, 2003; Van Cauwenberg and Cool, 1982). Whereas the exchange of knowledge between managers plays an important role in studies of strategy process research, quantitative research is lacking. In such studies, bottom-up knowledge flows are generally associated with exploratory processes such as competence definition processes (Floyd and Lane, 2000), or with autonomous strategic initiatives (Burgelman, 1983a; 1983b). Using quantitative data, this study illustrated that bottom-up knowledge inflows of managers relate to their exploration activities. Top-down knowledge flows are generally associated with exploitative processes such as competence deployment processes (Floyd and Lane, 2000), or induced strategic behavior (Burgelman, 1983a; 1983b). This study illustrated that top-down knowledge inflows of managers relate to their exploitation activities. Moreover, whereas studies of strategy process research tend to focus on knowledge flows across hierarchical levels, this paper illustrated the importance of managers' horizontal knowledge inflows as well, especially in terms of stimulating managers' exploration activities.

Our findings have limitations suggesting several issues for future research. The study involves cross-sectional, single informant data and uses perceptual scales highlighting issues of causal reciprocity and common method bias. Regarding the issue 
of causal reciprocity, confusion may exist regarding whether knowledge flows affect managers' exploration and exploitation activities, or whether the choice of activities affects the type of knowledge flows which come about. We recognized this potential confusion and addressed this issue in the paper by focusing on knowledge inflows only, and by indicating that both the knowledge donor and the knowledge recipient may be the initiator of such knowledge inflows. Further insight into the direction of causality between knowledge flows and exploration and exploitation activities could be created by examining knowledge outflows. Future research could examine how a manager's exploration and/ or exploitation activities impact upon the level and directionalities of knowledge outflows of this manager. At the organization unit level, Schulz (2001) shows that a unit's exploration and/ or exploitation activities impact upon the extent and kind of knowledge outflows of this unit (Cf. Schulz, 2001). Summarizing, we would argue that a manager's knowledge inflows impact upon this manager's exploration and exploitation activities, whereas these activities may influence the manager's knowledge outflows. Consequently, reciprocal causal relationships may exist between knowledge flows within a firm or unit and this manager's exploration and exploitation activities.

Regarding the issue of common method bias we performed Harman's one-factor test on items included in the regression models. If common method bias were a serious problem in the study, we would expect a single factor to emerge to account for most of the covariance in the dependent and independent variables (Podsakoff and Organ, 1986). We did not find such a single factor. The issue of common method bias could be addressed in future studies by measuring exploration, exploitation at the managerial level of analysis using objective measures.

Although a contribution of this paper is the development of scales which assess a manager's level of exploration and exploitation, and the validity and reliability analyses 
indicated that the scales were appropriately constructed, linking objective exploration and exploitation measures to the scales as used in this study could increase insight into the scales' validity. Furthermore, conducting this research in other industries could also help to better assess the validity and reliability of the scales and help to increase the generalizability of the findings.

The relevance of the findings could be further increased by examining the impact of managers' exploration and exploitation activities on unit- or organization-level performance, on incremental and radical innovations or on strategic renewal. Another interesting extension of our work could be to examine the relation between managers' exploration and exploitation activities, their knowledge inflows, and organizational elements, such as, for instance, organizational structural characteristics, controls, rewards, the social context, and coordination mechanisms (Duncan, 1976; Ghemawat and Ricart I Costa, 1993; Gibson and Birkinshaw, 2004; Jansen et al., 2005).

Despite these limitations, this paper furthers understanding of managers' exploration and exploitation activities and into how these activities may be influenced. This benefits our insight into how to build both exploration and exploitation within a firm, which will contribute to the firm's competitive advantage. 


\section{REFERENCES}

Adler, P., Goldoftas, B. and Levine, D. (1999). 'Flexibility versus efficiency? A case study of model changeovers in the Toyota production system'. Organization Science, 10, 43-68

Audia, P. G., Locke, E. A. and Smith, K. G. (2000). 'The paradox of success: An archival and a laboratory study of strategic persistence following radical environmental change'. Academy of Management Journal, 43, 837-53.

Bagozzi, R.P. and Phillips, L.W. (1982). 'Representing and testing organizational theories: A holistic construct'. Administrative Science Quarterly, 27, 459-89.

Bartlett, C. A. and Ghoshal, S. (1993). 'Beyond the M-form: Toward a managerial theory of the firm'. Strategic Management Journal, 14 (special issue), 23-46.

Benner, M. J. and Tushman, M. L. (2002). 'Process management and technological innovation: A longitudinal study of the photography and paint industries'. Administrative Science Quarterly, 47, 676-706.

Benner, M. J. and Tushman, M. L. (2003). 'Exploitation, exploration, and process management: The productivity dilemma revisited'. Academy of Management Review, 28, 238-56.

Bontis, N., Crossan, M., and Hulland, J. (2002). 'Managing an organizational learning system by aligning stocks and flows'. Journal of Management Studies, 39, 437-469.

Brady, T. and Davies, A. (2004). 'Building project capabilities: from exploratory to exploitative learning'. Organization Studies, 25, 1601-21.

Branzei, O., Ursacki-Bryant, T.J., Vertinsky, I. and Zhang, W. (2004). ‘The transformation of green strategies in Chinese firms: Matching corporate environmental responses and individual principles'. Strategic management Journal, 25, 1075-95. 
Brown, S.L. and Eisenhardt, K.M. (1997). 'The art of continuous change: Linking complexity theory and time-paced evolution in relentlessly shifting organizations'. Administrative Science Quarterly, 42, 1-34.

Burgelman, R.A. (1983a). 'A model of the interaction of strategic behavior, corporate context, and the concept of strategy'. Academy of Management Review, 8, 61-70.

Burgelman, R.A. (1983b). 'A process model of internal corporate venturing in the diversified major Firm'. Administrative Science Quarterly, 28, 223-44.

Burgelman, R.A. (1991). 'Intraorganizational ecology of strategy making and organizational adaptation: Theory and field research'. Organization Science, 3, 239-62.

Burgelman, R. A. (2002). 'Strategy as vector and the inertia of coevolutionary lock-in'. Administrative Science Quarterly, 47, 325-57.

Cheng, Y.T. and Van De Ven, A.H. (1996). 'Learning the innovation journey: Order out of chaos?'. Organization Science, 7, 593-614.

Crossan, M. M., Lane, H. W. and White, R.E. (1999). 'An organizational learning framework: From intuition to institution'. Academy of Management Review, 24, 52237.

Daft, R.L. and Lengel, R.H. (1986). 'Organizational information requirements, media richness and structural design'. Management Science, 32, 554-71.

Danneels, E. (2002). 'The dynamics of product innovation and firm competences'. Strategic Management Journal, 23, 1095-121.

Duncan, R. B. (1976). 'The ambidextrous organization: Designing dual structures for innovation'. In Kilmann, R.H., Pondy, L. R. and Slevin, D. (Eds), The Management of Organization. New York: North-Holland.

Egelhoff, W.G. (1991). 'Information-processing theory and the multinational enterprise'. Journal of International Business Studies, 22, 341-68. 
Fiol, C.M. and Lyles, M.A. (1985). 'Organizational learning'. Academy of Management Review, 10, 803-13.

Floyd, S. W. and Lane, P. J. (2000). 'Strategizing throughout the organization: Managing Role conflict in strategic renewal'. Academy of Management Review, 25, 154-77. Galbraith, J.R. (1973). Designing complex organizations. Reading: Addison-Wesley. Galunic, D.C. and Rodan, S. (1998). 'Resource recombinations in the firm: Knowledge structures and the potential for Schumpeterian innovation'. Strategic Management Journal, 19, 1193-201.

Garcia, R., Calantone, R. and Levine, R. (2003). 'The role of knowledge in resource allocation to exploration versus exploitation in technologically oriented organizations'. Decision Sciences, 34, 323-49.

Ghemawat, P. and Ricart I Costa, J. (1993). 'The organizational tension between static and dynamic efficiency'. Strategic Management Journal, 14, special winter issue, 5973.

Gibson, C. B. and Birkinshaw, J. (2004). 'The antecedents, consequences, and mediating Role of organizational ambidexterity'. Academy of Management Journal, 47, 209-26. Grant, R. M. (1996). 'Prospering in dynamically-competitive environments: Organizational capability as knowledge integration'. Organization Science, 7, 375-87.

Gupta, A. K. and Govindarajan, V. (1991). 'Knowledge flows and the structure of control within multi-national corporations'. Academy of Management Review, 16, 768-92.

Gupta, A. K. and Govindarajan, V. (2000). 'Knowledge flows within multinational corporations'. Strategic Management Journal, 21, 473-96.

Hair, J. F., Anderson, R. E., Tatham, R. L. and Black, W. C. (1998). Multivariate data analysis. Upper Saddle River, NJ: Prentice Hall.

He, Z. L. and Wong, P. K. (2004). 'Exploration vs. exploitation: An empirical test of the 
ambidexterity hypothesis'. Organization Science, 15, 481-94.

Hedlund, G. (1994). 'A model of knowledge management and the N-form corporation'. Strategic Management Journal, 15, Summer Special Issue, 73-90.

Henisz, W. J. and Macher, J. T. (2004). 'Firm- and country-level trade-offs and contingencies in the evaluation of foreign investment: The semiconductor industry, 1994-2002’. Organization Studies, 15, 537-54.

Holmqvist, M. (2004). 'Experimental learning processes of exploitation and exploration. An empirical study of product development.' Organization Science, 15, 70-81.

Huber, G. P. (1991). 'Organizational learning: The contributing processes and literatures'. Organization Science, 2, 88-115.

Iansiti, M. (2000). 'How the incumbent can win: Managing technological transitions in the semiconductor industry. Management Science, 46, 169-185.

Inkpen, A.C. (1996). 'Creating knowledge through collaboration'. California Management Review, 39, 1, 123-40.

Jansen, J.J.P., Van Den Bosch, F.A.J. and Volberda, H.W. (2005). 'Managing potential and realized absorptive capacity: How do organizational antecedents matter?'. Academy of Management Journal, 48, 999-1015.

Jansen, J.J.P., Van Den Bosch, F.A.J. and Volberda, H.W. (2006). 'Exploratory innovation, exploitative innovation, and performance: Effects of organizational antecedents and environmental moderators'. Management Science, forthcoming

Katila, R. and Ahuja, G. (2002). 'Something old, something new: A longitudinal study of search behavior and new product introduction'. Academy of Management Journal, 45, 1183-94.

Kimberly, J. R. (1979). 'Issues in the creation of organization: Initiation, innovation, and Institutionalization'. Academy of Management Journal, 22, 437-57. 
Kogut, B. and Zander, U. (1992). 'Knowledge of the firm, combinative capabilities, and the replication of technology’. Organizational Science, 3, 383-97.

Kogut, B. and Zander, U. (1993). 'Knowledge of the firm and the evolutionary theory of the multinational corporation'. Journal of International Business Studies, 24, 625-45.

Lawrence, P. R. and Lorsch, J. W. (1967). Organization and environment: managing differentiation and integration. Boston: Harvard Business School Press.

Leana, C.R. and Barry, B. (2000). 'Stability and change as simultaneous experiences in organizational life'. Academy of Management Review, 25, 753-59.

Leonard-Barton, D. (1995). Wellsprings of knowledge: Building and sustaining the sources of innovation. Boston: Harvard Business School Press.

Levin, D.Z. (2000) 'Organizational learning and the transfer of knowledge: An investigation of quality improvement'. Organization Science, 11, 630-47.

Levinthal, D. A. and March, J. G. (1993). 'The myopia of learning'. Strategic Management Journal, 14, 95-112.

Levitt, A. Y. and March, J. G. (1988). 'Organizational learning'. Annual Review of Sociology, 14, 319-40.

Lewin, A. Y., Long, C. P. and Carroll, T. N. (1999). 'The coevolution of new Organizational forms'. Organization Science, 10, 535-50.

Luo, Y. (2002). 'Capability exploitation and building in a foreign market: Implications for multinational enterprises'. Organization Science, 13, 48-63.

March, J. G. (1991). 'Exploration and exploitation in organizational learning'. Organization Science, 2, 71-87.

McGrath, R.G. (2001). 'Exploratory learning, innovative capacity, and managerial Oversight'. Academy of Management Journal, 44, 118-31. 
Mom, T.J.M., Van Den Bosch, F.A.J. and Volberda, H.W. (2005). 'Managing the tension between competence building and competence leveraging by influencing managerial and organizational determinants of horizontal knowledge exchange'. In Sanchez, R. and Heene, A. (Eds), Managing Knowledge Assets and Organizational Learning. Oxford: Elsevier.

Nerkar, A. (2003). 'Old is gold? The value of temporal exploration in the creation of new Knowledge'. Management Science, 49, 211-29.

Nonaka, I. (1994). ‘A dynamic theory of organizational knowledge creation'. Organization Science, 5, 14-37.

Nooteboom, B. (2000). Learning and innovation in organizations and economies. Oxford: Oxford University Press.

O'Reilly, C. A. and Tushman, M. L. (2004). 'The ambidextrous organization'. Harvard Business Review, 82, 4, 74-81.

Podsakoff, P. M. and Organ, D. W. (1986). 'Self-reports in organization research:

Problems and prospects'. Journal of Management, 40, 308-38.

Quinn, J. B. (1985). 'Managing innovation: Controlled chaos'. Harvard Business Review, 63, 3, 73-84.

Rajagopalan, N. and Spreitzer, G. M. (1996). 'Toward a theory of strategic change: A multi- lens perspective and integrative framework'. Academy of Management Review, 22, 48-79.

Rivkin, J. W. and Siggelkow, N. (2003). 'Balancing search and stability:

Interdependencies among elements of organizational design'. Management Science, 49, 290-311.

Rosenbloom, R.S. (2000). 'Leadership, capabilities, and technological change: The 
transformation of NCR in the electronic era'. Strategic Management Journal, 21, 108303.

Rosenkopf, L. and Nerkar, A. (2001).'Beyond local search: Boundary spanning, exploration, and impact in the optical disk industry'. Strategic Management Journal, 22, 287-306.

Sanchez, R. and Heene, A. (1996). A systems view of the firm in competence-based competition. In Sanchez, R., Heene, A. and Thomas, H. (eds.), Dynamics of competence-based competition: Theory and practice in the new strategic management: 39-62. Oxford: Elsevier Pergamon.

Schulz, M. (2001). 'The uncertain relevance of newness: Organizational learning and knowledge flows'. Academy of Management Journal, 44, 661-81.

Schulz, M. (2003). 'Pathways of relevance: Exploring inflows of knowledge into subunits of multinational corporations'. Organization Science, 14, 440-59.

Shepard, H. A. (1967). 'Innovation-resisting and innovation-producing organizations'. The Journal of Business, 40, 470-77.

Sheremata, W. A. (2000). 'Centrifugal and centripetal forces in radical new product development under time pressure'. Academy of Management Review, 25, 389-408.

Sidhu, J. S., Volberda H. W. and Commandeur H. R. (2004). 'Exploring exploration Orientation and its determinants: Some empirical evidence'. Journal of Management Studies, 41, 913-32.

Smith, K.G., Collins, C.J. and Clark, K.D. (2005). 'Existing knowledge, knowledge creation capability, and the rate of new product introduction in high-technology firms'. Academy of Management Journal, 48, 346-57. 
Subramaniam, M. and Venkatraman, N. (2001). 'Determinants of transnational new product development capability: Testing the influence of transferring and deploying tacit overseas knowledge'. Strategic Management Journal, 22, 359-78.

Subramaniam, M. and Youndt, M.A. (2005). 'The influence of intellectual capital on the types of innovative capabilities'. Academy of Management Journal, 48, 450-63.

Szulanski, G. (1996). 'Exploring internal stickiness: impediments to the transfer of best practice within the firm'. Strategic Management Journal, 17, Winter Special Issue, $27-$ 43.

Thompson, J.D. (1967). Organizations in action. New York: McGraw-Hill.

Tripsas, M. and Gavetti, G. (2000). 'Capabilities, cognition, and inertia: Evidence from digital imaging'. Strategic Management Journal, 21, 1147-61.

Tsai, W. (2001). 'Knowledge transfer in intraorganizational networks: Effects of network position and absorptive capacity on business unit innovation and performance'. Academy of Management Journal, 44, 996-1004.

Tsai, W. (2002). 'Social structure of “coopetition” within a multiunit organization: Coordination, competition, and Intraorganizational Knowledge Sharing'. Organization Science, 13, 179-90.

Tushman, M. L. and Anderson, P. (1986). 'Technological discontinuities and organizational environments'. Administrative Science Quarterly, 31, 439-65.

Tushman, M. L. and O’Reilly, C. A. (1996). ‘Ambidextrous organizations: Managing evolutionary and revolutionary change'. California Management Review, 38, 4, 8-30.

Van Cauwenbergh, A. and Cool, K. (1982). 'Strategic management in a new framework'. Strategic Management Journal, 3, 245-64.

Van Den Bosch, F.A.J. and Van Wijk, R. A. (1999). 'Transition processes towards the N- 
form corporation: Strategic implications for knowledge flows'. In Hitt, M.A., Clifford, P.G., Nixon, R.D. and Coyne, K.P. (Eds), Dynamic strategic resources: Development, diffusion and integration. Chichester: John Wiley \& Sons Ltd.

Van Den Bosch, F.A.J., Volberda, H.W. and De Boer, M. (1999). 'Coevolution of firm absorptive capacity and knowledge environment: organizational forms and combinative capabilities'. Organization Science, 10, 551-68.

Van De Ven, A.H. (1980). 'Problem solving, planning, and innovation. Part II.

Speculations for theory and practice'. Human Relations, 33, 757-79.

Vera, D. and Crossan, M. (2004). 'Strategic leadership and organizational learning'. Academy of Management Review, 29, 222-40.

Volberda, H. W. (1998). Building the flexible firm, how to remain competitive. Oxford: Oxford University Press.

Winter, S.G. and Szulanski, G. (2001). 'Replication as Strategy’. Organization Science, $12,730-34$

Zollo, M. and Winter, S.G. (2001). 'Deliberate learning and the evolution of dynamic capabilities'. Organization Science, 13, 339-51. 
Table I. Items and Factor Analysis of Managers' Exploration Activities, Exploitation Activities, Top-down Knowledge Inflows,

Horizontal Knowledge Inflows, and Bottom-up Knowledge Inflows

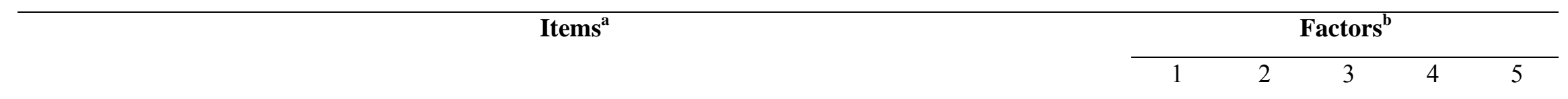

\section{Managers' Exploration Activities $(\alpha=.86)$}

To what extent did you, last year, engage in work related activities that can be characterized as follows:

Searching for new possibilities with respect to products/ services, processes or markets

Evaluating diverse options with respect to products/ services, processes or markets

Focusing on strong renewal of products/ services or processes

Activities requiring quite some adaptability of you

Activities requiring you to learn new skills or knowledge

$\begin{array}{ccccc}\mathbf{8 2} & -.13 & -.05 & .11 & .29 \\ \mathbf{8 4} & -.06 & -.03 & .01 & .26 \\ \mathbf{. 8 0} & -.05 & .14 & .13 & -.00 \\ .75 & .16 & -.06 & .10 & .15 \\ .65 & -.08 & .20 & .28 & -.03\end{array}$

\section{Managers' Exploitation Activities $(\alpha=.81)$}

To what extent did you, last year, engage in work related activities that can be characterized as follows:

Activities of which a lot of experience has been accumulated by yourself

Activities which serve existing (internal) customers with existing services/ products

Activities of which it is clear to you how to conduct them

Activities primarily focused on achieving short-term goals

Activities which you can properly conduct by using your present knowledge

Activities which clearly fit into existing company policy

$\begin{array}{ccccc}.23 & .62 & .09 & -.02 & -.15 \\ -.13 & .73 & .01 & .14 & .06 \\ .02 & .71 & .10 & .33 & -.09 \\ -.22 & .62 & .12 & -.08 & .19 \\ -.05 & .82 & .17 & -.05 & .07 \\ .03 & .73 & .10 & -.03 & .09\end{array}$


Managers’ Top-down Knowledge Inflows $(\alpha=.79)$

To what extent did you, last year, receive or gather knowledge from:

Your direct supervisor

$\begin{array}{lllll}.02 & .19 & \mathbf{8 0} & .15 & .05\end{array}$

One more hierarchical level up than your direct supervisor

$\begin{array}{lllll}.01 & .13 & .92 & .04 & .09\end{array}$

Two more hierarchical levels up than your direct supervisor

$\begin{array}{lllll}.10 & .15 & .73 & .19 & .15\end{array}$

\section{Managers’ Horizontal Knowledge Inflows $(\alpha=.74)$}

To what extent did you, last year, receive or gather knowledge from:

Peer teams within your own organizational unit

Peer teams in other organizational units within your own division

Peer teams in other divisions

$\begin{array}{rrrrr}.02 & -.05 & .14 & .78 & .28 \\ .22 & .17 & .10 & .81 & .13 \\ .33 & .04 & .20 & .71 & -.16\end{array}$

\section{Managers’ Bottom-up Knowledge Inflows $(\alpha=.80)$}

To what extent did you, last year, receive or gather knowledge from:

Your direct assistants

$\begin{array}{lllll}.21 & .05 & .15 & .13 & .86\end{array}$

One more hierarchical level down than your direct assistants

$\begin{array}{lllll}.33 & .12 & .16 & .09 & .76\end{array}$

Eigenvalue

$\begin{array}{lllll}3.45 & 3.18 & 2.27 & 2.10 & 1.72\end{array}$

Percentage of variance explained

18.2

$16.7 \quad 11.9 \quad 11.1$

9.04

${ }^{\mathrm{a}}$ Items are quoted from our survey. All items were measured on a seven-point scale $(1=$ to a very small extent to $7=$ to a very large extent).

${ }^{\mathrm{b}}$ Extraction Method: Principal Component Analysis. Rotation Method: Varimax with Kaiser Normalization. 
Table II. Means, Standard Deviations, and Correlations

\begin{tabular}{|c|c|c|c|c|c|c|c|c|c|c|c|c|c|}
\hline & Mean & $\begin{array}{l}\text { St. } \\
\text { dev }\end{array}$ & 1 & 2 & 3 & 4 & 5 & 6 & 7 & 8 & 9 & 10 & 11 \\
\hline 1 Exploitation Activities & 5.27 & .77 & & & & & & & & & & & \\
\hline 2 Exploration Activities & 5.28 & .94 & -.05 & & & & & & & & & & \\
\hline 3 Top-down Knowledge Inflows & 3.78 & 1.22 & .32 & .14 & & & & & & & & & \\
\hline 4 Bottom-up Knowledge Inflows & 5.56 & 1.06 & .14 & .42 & .30 & & & & & & & & \\
\hline 5 Horizontal Knowledge inflows & 4.60 & .92 & .15 & .39 & .35 & .29 & & & & & & & \\
\hline 6 Product Market unit 1 & .09 & .28 & -.28 & .23 & -.19 & -.03 & .05 & & & & & & \\
\hline 7 Product Market unit 2 & .20 & .40 & -.16 & .02 & .02 & .02 & -.08 & -.16 & & & & & \\
\hline 8 Product Market unit 3 & .07 & .25 & .04 & -.01 & .20 & .11 & -.05 & -.08 & -.14 & & & & \\
\hline 9 Product Market unit 4 & .13 & .34 & .03 & .03 & .02 & .02 & .09 & -.12 & -.20 & -.11 & & & \\
\hline 10 Product Market unit 5 & .33 & .47 & .13 & -.13 & .04 & .01 & .04 & -.22 & -.35 & -.19 & -.28 & & \\
\hline 11 Function: R\&D & .47 & .50 & -.15 & .14 & -.20 & -.08 & .02 & .12 & -.14 & -.10 & -.09 & .16 & \\
\hline 12 Function: Marketing \& Sales & .13 & .34 & -.09 & .23 & .11 & .20 & .06 & .08 & -.06 & .12 & .01 & .09 & -.37 \\
\hline
\end{tabular}


Table III' ${ }^{\mathrm{a}}$. Results of Hierarchical Regression Analysis: Managers' Exploitation Activities and Managers' Exploration Activities

\begin{tabular}{|c|c|c|c|c|c|c|c|c|}
\hline \multirow[b]{3}{*}{ Control Variables } & \multicolumn{4}{|c|}{ Exploitation Activities } & \multicolumn{4}{|c|}{ Exploration Activities } \\
\hline & \multicolumn{2}{|c|}{ Model 1a } & \multicolumn{2}{|c|}{ Model 1b } & \multicolumn{2}{|c|}{ Model 2a } & \multicolumn{2}{|c|}{ Model 2b } \\
\hline & b (s.e.) & $\beta$ & b (s.e.) & $\beta$ & b (s.e.) & $\beta$ & b (s.e.) & $\beta$ \\
\hline Product Market unit 1 & $-.84(.18)$ & $-.31 * *$ & $-.77(.30)$ & $-.28 *$ & $.49(.37)$ & .15 & $.47(.33)$ & .14 \\
\hline Product Market unit 2 & $-.53(.23)$ & $-.27 *$ & $-.56(.23)$ & $-.29 *$ & $.11(.28)$ & .05 & $.08(.25)$ & .03 \\
\hline Product Market unit 3 & $-.12(.33)$ & -.04 & $-.29(.33)$ & -.09 & $-.12(.40)$ & -.03 & $-.23(.36)$ & -.06 \\
\hline Product Market unit 4 & $-.20(.26)$ & -.09 & $-.26(.25)$ & -.11 & $.09(.32)$ & .03 & $-.03(.28)$ & -.01 \\
\hline Product Market unit 5 & $-.02(.22)$ & -.01 & $-.08(.21)$ & -.05 & $-.30(.26)$ & -.15 & $-.36(.23)$ & -.18 \\
\hline Function: R\&D & $-.34(.16)$ & $-.22 *$ & $-.29(.16)$ & -.19 & $.53(.20)$ & $.28 * *$ & $.51(.18)$ & $.27 * *$ \\
\hline Function: M\&S & $-.35(.24)$ & -.16 & $-.41(.23)$ & -.18 & $.93(.29)$ & $.34 * *$ & $.71(.26)$ & $.26 * *$ \\
\hline \multicolumn{9}{|l|}{ Knowledge Inflows } \\
\hline Top-down & & & $.15(.07)$ & $.24 *$ & & & $.02(.07)$ & .02 \\
\hline Bottom-up & & & $.06(.07)$ & .09 & & & $.28(.08)$ & $.32 * *$ \\
\hline Horizontal & & & $.05(.09)$ & .06 & & & $.27(.09)$ & $.26 * *$ \\
\hline R-squared & & .17 & & .26 & & .17 & & .39 \\
\hline Adjusted R-squared & & .11 & & .18 & & .11 & & .33 \\
\hline F improvement of fit & & $2.85 *$ & & $3.46^{*}$ & & $2.83 * *$ & & $11.18 * * *$ \\
\hline
\end{tabular}

${ }^{\mathrm{a}}$ Unstandardized coefficients are reported, with standard errors in parentheses, as well as standardized coefficients.

$\mathrm{N}=104 ; * p<.05 ; * * p<.01 ; * * * p<.001$ 


\section{Publications in the Report Series Research ${ }^{*}$ in Management}

\section{ERIM Research Program: "Strategy and Entrepreneurship"}

\section{6}

Modeling Brand Extension as a Real Option: How Expectation, Competition and Financial Constraints Drive the Timing of Extensions Lenny H. Pattikawa

ERS-2006-030-STR

http://hdl.handle.net/1765/7855

Coping with Problems of Understanding in Interorganizational Relationships: Using Formalization as a Means to make Sense Paul W.L. Vlaar, Frans A.J. Van den Bosch and Henk W. Volberda

ERS-2006-034-STR

http://hdl.handle.net/1765/7879

On the Evolution of Trust, Distrust, and Formal Coordination and Control in Interorganizational Relationships: Towards an Integrative Framework

Paul W.L. Vlaar, Frans A.J. Van den Bosch and Henk W. Volberda

ERS-2006-035-STR

http://hdl.handle.net/1765/7877

Complex Incremental Product Innovation in Established Service Firms: A Micro Institutional Perspective

Patrick A.M. Vermeulen, Frans A.J. Van den Bosch and Henk W. Volberda

ERS-2006-037-STR

http://hdl.handle.net/1765/7880

Exploratory Innovation, Exploitative Innovation, and Performance: Effects of Organizational Antecedents and Environmental Moderators

Justin J.P. Jansen, Frans A.J. Van den Bosch and Henk W. Volberda

ERS-2006-038-STR

http://hdl.handle.net/1765/7892

Preservation and Dissolution of the Target Firm's Embedded Ties in Acquisitions Simona Spedale, Frans A.J. van den Bosch and Henk W. Volberda ERS-2006-077-STR

Investigating Managers' Exploration and Exploitation Activities: The Influence of Top-down, Bottom-up, and Horizontal Knowledge Inflows

Tom J.M. Mom, Frans A.J. Van Den Bosch and Henk W. Volberda

ERS-2006-078-STR

\footnotetext{
* A complete overview of the ERIM Report Series Research in Management: https://ep.eur.nl/handle/1765/1

ERIM Research Programs:

LIS Business Processes, Logistics and Information Systems

ORG Organizing for Performance

MKT Marketing

F\&A Finance and Accounting

STR Strategy and Entrepreneurship
} 